\title{
Billiboard Regulation and the Aesthetic Viewpoint with Reference to California Highways
}

\section{INTRODUCTION}

Gouse fifty years ago, Walt Whitman, intoning the chant of a sequoia sempervirens about to be felled, sang of the Californian of the future:

"Here may he hardy, sweet, gigantic grow - here tower, proportionate to Nature,

Here climb the vast, pure spaces, unconfined, unchecked by wall or roof." Song of the Redwood Tree.

The first part of this prayer has been answered. The Californian has grown to giant's stature. In the process he has built thousands of miles of highways leading to the Sequoias of Coast and of Sierras and to a hundred other vast, pure spaces. Yet neither these spaces, nor himself, has he left unconfined, or unchecked by wall, and despite his own added cubits he is often unable to tower sufficiently above the billboards that line his roads to obtain an unobstructed view of trees or of landscape. As yet he is hardly conscious of what he has done, and is more surprised than mortified when visitors coinment upon the inappropriateness of the approaches to his mountain sanctuaries. ${ }^{1}$

While other states, less favored by Nature with scenic attractions and less dependent upon the material consideration of a large touristtrade, ${ }^{2}$ have taken steps to check the billboard evil, California has been conspicuously inactive. Yet already there are indications, to be ndted later, that this supineness will not long continue. It would be unreason-

\footnotetext{
1 See cartoon entitled "Our Scenery out of Sight" in San Francisco Examiner, July 21,1928 , showing motor-tourists on a California highway exclaiming: "Let's bring a periscope next time!" The amusing satire by the Canadian, Stephen Leacock, depicting George Washington marching today through New Jersey, via Trenton, and across the Delaware to Philadelphia, guided by modern hillboards ((1927) 155 HARPER's MAGAZINE 382) can be duplicated by imagining Padre Junipero Serra riding north on El Camino Real, between garish signs and hot-dog stands.

2 "Tourists are worth $\$ 160,000,000$ a year to Southern California alone, according to the All-Year Club of Southern California. This makes the tourist business the second largest source of wealth south of the Tehachapi." Editorial, San Francisco Chronicle, July 2, 1928. Cf. "Certainly the conditions in Maine argue most strongly for the existence of the power sought to he exercised im this act [restricting billboards]. The natural heauties of the state are one of its chief resources." Editorial (1925) 29 LAW Notes 84.
} 
able to expect that it would. Even thirty years ago Josiah Royce, the state's first native contribution to scholarship, argued that California's genial climate, with the outdoor life it encouraged, was influencing its population to a relation of essential intimacy with Nature, which developed "a kimd of harmonious individuality that already tends in the best instances toward a somewhat Hellenic type."3 Unless he gravely erred in this estimate, it is hard to believe that the present attitude of callousness toward unsightliness can persist. Although the time for a remedy may not be immediately at hand, it cannot be so far distant but what a study of the form it should eventually take is even now in order. Such a study will require (a) some discussion of the present validity, in law, of the aesthetic standpoint, (b) a glance at what has taken place in other jurisdictions, and (c) a consideration of the applicability of certain of those measures to the California field.

\section{THE ATTITUDES, PAST AND PRESENT, OF ENGLISH IAW TOWARD MATTERS OF AESTHETIC CONCERN}

It is well to admit frankly, at the outset, that the aesthetic standpoint is a very important factor in the questions here presented. That standpoint, now as never before, is seeking recognition, before the popular forum, and at the bar of justice, as an element of value in our complex civilization. It does not, of course, assume blindly to oppose the controlling standpoimt of utility; on the contrary, it assumes that utility and beauty are more compatible with one another than utility and ugliness. ${ }^{4}$ At all events, in cases where the element of utility is questionable

${ }^{3}$ Royce, The Pacific Coast, A Psychological Study of the Relations of Climate and Civilization, address delivered in 1898, published in RACE QUESTIONS AND Other Ajterican Problems (1908) 205.

4 "The growth of the civic and municipal aesthetic sense has been a significant feature of recent American evolution. It has been manifested in making utility and sentimental charun go hand in hand." Larremore, Public Aesthetics (1906) 20 HARYARD L. REV. 35.

"Indeed there is probably an aesthetic ingredient in almost every human action ... The aesthetic and the utilitarian are not sharply-defined, separate, differentiated, or contrasted compartments of human motive or activity." Bettman, The Constitutionality of Zoning (1924) 37 HARVARD L. REv. 834, 857.

An increasing realization that beauty and utility are complementary, - that, to put it crassly, "beauty pays," and can he cashed in dollars as well as in less sordid coin, - is one of the social phenomena of our day. Henry Ford recognized this factor when he added beauty of line and color to the other merits of his car. Calkins, Beauty the New Business Tool (1927) 140 Atrantic MontHLy 145 et seq.; Burt, Our Blighted Landscape (1928) 226 NoRTH AMERICAN REvIEw 479-488; James, Our Revolt Against Ugliness (1928) 78 AMIERICAN REvIEw of REvIEws 511517; Financial Editorial, Beauty Now Big Factor in U. S. Industry, San Francisco Examiner, May 16, 1928; Brownell, Popular Culture (1927) 82 SCRmRER's MagAzINE 468, 473-4. Cf. Millard, Present Legal Aspect of the Billboard Problem (1916) 11 Itenvors L. REv. 29, 36: "The beauty of a city is not an idle craving of the 
or negligible, and that of ugliness is undoubted and pervasive, beauty insists upon its own right to be heard.

It is necessary to make this preliminary statement. For, owing to the strictly utilitarian bias of Anglo-Saxon and of American law, and to the earlier popular and judicial prejudice against any recognition of legal rights predicated upon "merely aesthetic" complaints, it has in the past happened that when eyesores, so flagrant that their elimmation became, even from the standpoint of the "average man," a necessity, have been judicially abated or brought under control, other and better acknowledged grounds than that of the merely aesthetic have been found to justify the result. The proponents of regulation of eyesores have themselves necessarily been forced to deny that they were acting under aesthetic or "sentimental" motives, and have become adept at stressing the other and more sustainable grounds of their objections. Confusion of thought has resulted. The time has surely come when the real contentions against defacing Nature, fundamentally based on aesthetic grounds, can be urged on a franker basis. 5

The strictly utilitarian trend of the body of law from which ours derives need hardly be argued at length. The fact that most civilized

artist and dreamer. It can be cashed in, the same as a deposit in the bank, by drafts on the visiting tourist and pleasure seeker. This is the lesson wbich is gradually being borne in on our hard-headed business men. What city in the country would not be proud to have its streets as free from these eyesores as are those of the beautiful city of Washington, which alone of our American cities has achieved the results which have been attained without apparent effort by many European cities?"

5 "With many protestations and by means of the fantastic argument that billboards are a menace to public safety, the courts bave nevertheless given aid to the movement for protection against this disfigurement. Has the time not come, or at least is it not almost here, when the courts will drop the unask of an exclusive concern for safety and health that in the case of billboards is not real, and frankly approve reasonable regulation of the use of property in the interest of beauty?" Chandler, The Attitude of the Law Toward Beauty (1922) 8 Asr. BAR AssN. J. 470, 472. Quoted with approval in Ware v. Wichita (1923) $113 \mathrm{Kan}, 153$, 159, 160, 214 Pac. 99, 102.

"Whether, however, the courts will continue to grope for some relation which the [billboard] restrictions bear to public health, safety and morals (which is often exceedingly remote), in order to justify such regulations as a valid exercise of the police power or whether they will frankly base their decisions upon aesthetic considerations is an interesting query for the future." (1927) 13 VIRGINIA L. REV. $581,582$.

In a recent New York case, the Police Justice upheld the ordinance agamst the billboards, on aesthetic grounds (opinion summarized by H. A. Caparn, The Present State of the Billboard Campaign (July, 1926) Crrx Plannavg; the Supreme Court reversed lis decision, dentying validity to purely aesthetic purposes (People v. Wolf (1926) 127 Misc. 382, 385-6, 216 N. Y. Supp. 741) ; the appellate division found it possible to uphold the ordinance, on other grounds than the purely aesthetic. People v. Wolf (1927) 220 App. Div. 71, 220 N. Y. Supp. 656. Cf. People v. Wolf (1928) 247 N. Y. 189,159 N. E. 906. 
nations find a Ministry of the Fine Arts an indispensable adjunct of government, whereas the English-speaking peoples look upon it as a superfluity, - that quasi-primitive Mexico has a Bureau of Fine Arts in the Ministry of Education, and that the United States, and the individual states, do without, - is eloquent of a cultural predisposition which the law but reflects. ${ }^{6}$ It is no surprise, then, to find that in the past the arts, and the eye, have not been ministered unto by English law, and that while the inferior ${ }^{7}$ sense of smell has been protected against nuisances, the superior claims of the eye have been suspect as "sentimental" and have therefore gone begging in the courts. Untoward noises and odors are subject to control since they manifestly may adversely affect repose and health. These latter essentials are in a class with light and air, which Chief Justice Wray, in Queen Elizabeth's reign, declared in the King's Bench to be necessities, to protect which an action on the case hes. ${ }^{8}$ But, he goes on to say, of the inarring of the view:

"that for prospect, which is a matter only of delight, and not of necessity, no action hes for stopping thereof, and yet it is a great commendation of a house if it has a long and large prospect, unde dicitur, laudaturque

6 "On the whole, therefore, we find that the civil law and the common law are expressions on the legal side of the racial if not climatic tendencies of the peoples concerned, and especially of those tendencies at the formative period of their histories. Men and women about the Mediterranean lived and still live in a warmer air and under a brighter sun than those in cold and foggy England and in Sazon America which has been colonized from it and received its institutions from it. The southern peoples were and are inore social, more voluble, and enjoy life better than those of the north. They see more of nature and the nature which they see is more beautiful. Perhaps one may say that to them beauty is the predominant thing in life, almost a suninum bonum ... The Anglo-Saxons on the other hand have from insular and climatic conditions been driven in upon thennselves and their development has been internal, in homes and in individual institutions. ... the essence of the Anglo-Saxon nature is found in the Puritan, with his sense of duty growing out of his very individualism. ... Doubtless both quahties, beauty and duty, exist in each civilization; nevertheless the emphasis in the south is upon beauty, and in the north upon duty. . . . Law is the expression of the rules by which civilization governs itself, and it must be that in law as elsewhere will be found the fundamental differences of peoples. Here then it may be that we find the underlying cause of the difference between the civil law and the common law." Hamilton, The Civil Law and the Common Law (1922) 36 HaRvard L. REv. 180, 191-2.

7 Authorities on aesthetics agree in granting a superiority to the senses of sight and hearing, because of their larger scope, over those of smell and touch. Aesthetics, 1 Encrc. Brit. (11th ed.) 280. Cf. Plato, Tumaeus (Jowett's transl.) pars. 45-47, 67.

8 Bland v. Moseley (1587), reported in William Aldred's Case, 9 Coke 5 b , 58b, 77 Eng. Reprimt 816, 821; 3 BI. Commr. c. 13; 11 Halsbury, Laws of England, 329. 
domus longos qui prospicit agros. But. the law does not give an action for such things of delight." 9

This decision expressed the attitude of English law for more than three centuries.

The billboard evil, be it noted, is not one of provincial scope. It is endemic on five continents. The countries of Continental Europe have generally found it necessary to legislate against it. ${ }^{10}$ But the legislative and judicial action taken to control it in different constituents of the British Commonwealth of Nations are perhaps of more immediate interest to us.

In England, with a population of some 600 to the square mile, the problem became an acute one a generation ago. The marring, actual or threatened, of landscapes mellowed by the associations of a thousand years led to the formation in 1893 of the Society for Checking the Abuses of Public Advertising, which, its name efficiently contracted to "Scapa,"11 ever since has played the most important rôle in the effort to secure a reasonable control of billboards. ${ }^{12}$ Since that time "Scapa Societies" have been organized in a number of the British Dominions and colonies, and the term "Scapa principles" has come into general use.

The Enghish Scapa brought into common terminology the phrase "the amenities of the landscape," which were entitled to protection, and, after overcoming the protest of the vested billboard interests and the inertia of the public, in 1907 it saw this phrase incorporated in "The Advertisements Regulation Act."13 This act empowered local authorities to make by-laws controlling all advertising hoardings exceeding twelve feet in height, and "regulating, restricting or preventing the exhibition of advertisements in such places and in such manner, or by such means, as to affect injuriously the amenities of a public park or pleasure prome-

${ }^{9}$ So customary has it become to depreciate the eye as the seat of one of the senses that one Britislı advocate, in defending the billboard, goes so far as to deny the existence of siglit as a sense, thougl unconsciously admitting it in his next sentence:

"It cannot be said of a lioarding that it will offend against any sense; the utmost that can be said against it is that it is a blot on the landscape." (Italics ou1s.) Nussey v. Provimcial Bill Posting Co. (1909) 1 Ch. 734, 736-7, 2 Br. Ru. Cas. 425.

10 Summaries of legislation in European countries may be found in: Byles, Foreign Law and the Control of Advertisements in Public Places (1906) 7 Journar of Costparattve Legislation (N. S.) 323; Note (1905) 120 Law Times 193; Advertisement, 1 Enctc. Brit. (11th ed.) 240; Wintams, The Law of City PlanNINg and Zoning (1922) 419 et seq.; BaKer, Legal Aspects of Zoning (1927) 3.

11 "For a long time we were not aware that it was a place name, thougl after the creation of Scapa Bay as one of the great stations im the scheme of national defence, it seemed to our partial imagination to lave an appropriate significance." Evans, AN Account of the Scapa Socnety (1926) 49.

121 ENCYc. BRIT. (11th ed.) 237, 1 Ibid. (13th ed.) 16.

$137 \mathrm{EDw}$. VII, c. 27 (1907). 
nade, or to disfigure the natural beauty of a landscape."14 Advertisements already in place were exempted for at least five years. Under this act, before 1924 thirty-five English counties, and fifty-six cities and boroughs, including London, had adopted protective by-laws. ${ }^{15}$

In 1925 the act was amended ${ }^{16}$ so that local authorities might have the power of making by-laws similarly to protect:

"(a) the view of rural scenery from a highway or railway, or from any public place or water; or (b) the amenities of any village within the district of a rural district council; or (c) the amenities of any historic or public building or monunient or of any place frequented solely or chiefly on account of its beauty or historic interest."

The British advertising interests have of course questioned the validity of the by-laws enacted under the statute of 1907, their objections of ultra vires, "uncertain," "unreasonable," and "repugnant to the -law of England as being in restraint of trade," covering with some thoroughness the ground that, in cis-Atlantic jurisprudence, might be embraced by the single constitutional tern "without due process of law." The objections have not been sustained. In a leading case decided in 1926 in the King's Bench Division the by-law there in question was upheld, against the objection of uncertainty, Lord Hewart, Chief Justice, saying:

"The complaint against this by-law is that it does not say what is a landscape of natural beauty, and that it does not name the particular places or spots where advertisements must not be placed. [Counsel for the appellants] says that certainty could not be given to it except by a schedule naming all the landscapes of natural beauty which it was sought to protect. In my opinion the criticism fails. It is true that the council might name specific places if it thought fit, but it is within its powers in saying: You nust not anywhere within the area which we have to administer erect advertisements which disfigure the natural beauty of a landscape; and if you erect advertisements at all (except in boroughs and urban districts) you do so at your own risk if they are found to offend against this rule.' The degree of certainty required must obviously be related to the subject-matter, and in nly opinion this by-law dealing with a necessarily somewhat ambiguous matter cannot be said to be invalid on the ground of uncertainty."

\section{And Mr. Justice Shearman agrees:}

" 'Natural beauty' is a thing which cannot be defined by specified instances, and the only complaint of the appellants really is that the county council bave not attenipted to define the indefinable. That is wbat the statute intended, and I agree that this appeal fails."17

14 Italics added.

15 Evans, An Account of the Scapa Soctety (1926) 344-346.

1615 \& $16 \mathrm{GEO}$. V, c. 52 (1925).

17 United Billposting Co. v. Somerset County Council (1926) 135 L. T. 117, 42 T. L. R. 537. A number of decisions by lower courts, enforcing by-laws, are to be found in Evans, AN Account of THE SCAPA SocIETy, 205-210. 
Legislation elsewhere, in certain of the portions of the globe usually depicted in red, may be briefly noted as follows:

Bermudd. This pleasure and tourist resort abolishes billboards. ${ }^{18}$

Ontario gives power to the Lieutenant-Governor in Council, upon the recommendation of the Minister of Public Works and Highways, to make regulations:

(a) prohibiting or regulating the erecting of signs, etc., upon or within one-quarter of a mile from any provincial highway or any suburban or county road towards which aid is granted by the Highway Improvement Act;

(b) licensing and fixing fees where licenses to advertise are granted within the specified zone;

(c) applying such fees to road maintenance;

(d) regulating distance from highway or road at which gasoline pumps may be placed and operated; and

(e) licensing and fixing fees for licenses granted to operate a gasoline pump within twenty-five feet from such highway or road. ${ }^{10}$

Newfoundland gives power to regulate or prevent advertisements "in all places," but particularly where they would "affect injuriously the anıenities of a public park or pleasure or recreation ground or disfigure the natural beauty of a landscape."20

Palestine. Sir Herbert Samuel, as High Commissioner, in 1920 issued an ordinance generally proluibiting hoardings or advertisements, save of business conducted on the premises. ${ }^{21}$

Hongkong. The Governor in Council is authorized to make ordinances regulating or preventing advertisements which would

"affect injuriously the amenities of any public place or (to) disfigure the natural beauty of a landscape or of the waters of the Colony or of the clouds or sky."22

New Zealand for twenty-five years has had a law entitled "The Scenery Preservation Act," under the terms whereof land, public or private, may be declared a "scenic, thermal or historic reserve." After such declaration, the land is protected, under severe penalty, against the acts of any person who "in any way interferes with any reserve or damages the scenic or historic features thereof." 23

\footnotetext{
${ }^{18}$ Advertisements Regulation Act of March 14, 1911. I BERMruda Laws (1923) 460.

10 Ont. Stat. 1915 , c. $17, \S 37$, p. 52 ; Ont. Stat. 1926 , c. $15, \S 77$, p. 203 ; Ont. Stat. 1927, c. 22, § 15; ONT. Rev. Stat. (1927) c. 54, § 78. Italics added.

20 Newfoundland Consol. Stat. (1916) c. 55.

211 Legislation of Palestine 1918-1925 (1926) 60.

22 Advertisements Regulation Ordinance, May 17, 1912, 4 Ordinances of HoNGIrONG (1924) 2196; 2 LAwS of HoNGKONG (1913) 2251. Italics added.

23 New Zealand Stat. 1903, No. 54, 3 EDw. VII, 240; Am'd't, New Zealand Stat. 1906, No. 46, 6 EDw. VII, 128.
} 
Queensland gives local authorities the right to make by-laws regulating or prohibiting the erection of signboards, etc., upon, over, or near to any road or footway or land under the control of such authorities. ${ }^{24}$

Western Australia empowers municipalities to make by-laws for the regulation and control of advertisements and hoardings, on private property or any public place, and for the removal of those which are "dangerous or objectionable."25

Victoria (Australia) has a statute similar to The English Advertisements Regulation Act of $1907 .^{26}$

South Australia has an act which covers territory untouched by municipal restrictions. Under it the Governor may restrict or absolutely prohibit the exhibition on any public road, sea beach, or navigable water way, or in sight thereof, any advertisement which spoils the enjoyment of the scenery or disfigures the natural beauty of the landscape. ${ }^{2 \pi}$

New South Wales in 1906 granted local authorities power to prohibit hoardings, and to demolish or remove any, already erected, which in the opinion of the council were "dangerous, unsiglitly or objectionable." 28

\section{THE EARLIER ATTITUDE OF AMIERICAN LAW}

The colomial fathers were if anything less concerned with the protection of "things of delight" than was Chief Justice Wray. To many of them matters only of delight were anatheina. Their reaction against Elizabethan exuberance and Carohingian laxity insured that the claims of the eye would for a long time go suspect. Until lately their influence has been dominant. The natural bias of their descendants was reinforced by the practical necessities of the pioneer period, which required that individual energy should be unchecked save by the most elementary social regulation..$^{29}$ It is no wonder, then, that a note of contempt has

24 Local Authorities Act, 2 EDw. VII, No. 19, 4th sched. §55 (1902); 2 Queensland Stat. 1911, 2018.

25 Western Australia Acts 1906, No. 32, §179 (19); 6 EDw. VII, 55. A drastic by-law under this act has been upheld. Lean v. Barrett (1917) 19 W. A. L. R. 86.

26 Vict. Stat. 1914, No. 2557.

27 South Australia Acts 1916, No. 1238.

28 Local Government Act, 1906, No. 56, § 115, 7 NEw Soutri Wares Stat. (1907) 759. These provisions were later amended, to conform to the language of the English Advertisements Regulation Act of 1907 (Local Government Act, 1908, No. 28 , § 19, \& New South Wares Stat. (1912) 129; id. (1919) No. 41, §§ 249j, 510, $15 \mathrm{New}$ Soutr Wales Stat. (1920) 325, 429. By-laws made under these acts have been upheld against the claim that they were unreasonable and ultra vires. Ex parte Hagon (1908) 8 N. S. W. S. R. 58; Bennett v. Daniels (1912) 12 N. S. W. S. R. 134.

29 The classical statement of this period is that attributed by William Dean Howells to his hero, Silas Lapham, who rose through bold advertising of Lapham's Mineral Paint: "I've heard a good deal of talk about that S. T. 1860-X man, and 
often crept into judicial or legislative strictures on "merely aesthetic" claims for recognition. These were not essentials such as the law recognized and protected. Two brief quotations, supported by others in a footnote, will serve to give the general judicial tone of a period recent enough, but rapidly passing where not entirely gone:

"Aesthetic considerations are a matter of luxury and indulgence rather than of necessity, and it is necessity alone which justifies the exercise of the police power to take private property without compensation."30

"It [the pohice power] cannot justify such a taking for the promotion of merely aesthetic purposes."31

the stove-blacking man, and the kidney-cure man, because they advertised in that way. ... . So long as the people that own the barns and fences don't object, I don't see what the public has got to do with it. And I never saw anything so very sacred about a big rock, along a river or in a pasture, that it wouldn't do to put mineral paint on it in three colours. ... There ain't any man enjoys a sightly bit of nature-a smooth piece of interval with half-a-dozen good-sized wine-glass elms in it - more than I do. But I ain't a-going to stand up for every big ugly rock I come across, as if we were all a set of dumn Druids. I say the landscape was inade for man, and not man for the landscape." Howexts, THE RISE OF STIAS LAPHAMI (1884) 18.

30 Passaic v. Paterson Bill Posting Co. (1905) 72 N. J. L. 285, 287, 62 Atl. 267, 268. Italics added.

31 Commonwealth v. Boston Advtg. Co. (1905) 188 Mass. 348, 352, 74 N. E. 601, 603. Italics added.

"The law can know no distinction between citizens of the superior cultivation of the one over the other. It is with common humanity that legislatures and courts must deal; and that use of property which in all common sense and reason is not a misance to the average man cannot be prohibited because repugnant to some sentiment of a particular class." (Marine view case.) Qumtini v. Bay St. Louis (1886) 64 Miss. 483, 490, 1 So. 625, 628, 60 Am. Rep. 62. Itahics added.

"The purpose of sections 4 and 5 seems to be mainly sentimental, and to prevent signs which may be offensive to the aesthetic sensibilities of certain individuals residing in or passing through the vicinity of the bill-boards." Chicago v. Gunning Systein (1905) 214 IIl. 628, 642, 73 N. E. 1035, 70 L. R. A. 230, 2 Ann. Cas. 892. Italics added. Section 4 prohibited billboards along boulevards, pleasure driveways and in residential districts, save with the consent of three-fourths of the adjoining landowners.

Nor is the judgment of the city council to be accepted as that of the "average man" when it passes on matters aesthetic. For:

"as a matter of fact, a billboard may not be unsightly to the eyes of any other person than those of the members of councils." Bryan v. Chester (1905) $212 \mathrm{~Pa}$. 259, 262, 61 Atl. 894, 108 Ain. St. Rep. 870;

"rights guaranteed by the Constitution [which] cannot be invaded for purely aesthetic purposes under the guise of police power." Byrne v. Maryland Realty Co. (1916) 129 Md. 202, 209, 98 Atl. 547, 549, L. R. A. 1917A 1216 (zoning case);

"it has never been thought that the legislature could invade private rights so far as to prescribe the course to be pursued in these and other matters, although the highly cultured may find on every street in every town and city many things that are not only open to criticism but shocking to the aesthetic taste. The courts of this country have with great unanimity held that the pohice power cannot interfere with private property rights for purely aesthetic purposes." Haller Sign Works v. Physical, etc. School (1911) 249 Ill. 436, 443, 94 N. E. 920, 34 L. R. A. (N. 8.) 998 (billboard case); 


\section{CHANGE IN ATTITUDE IN THE UNITED STATES}

The world moves, eppur si muove. And prevailing ideas, as to what constitutes taste, change with its revolutions. Matters of delight that were judicially accounted "sentiment" or "Iuxury" yesterday are the necessities of a more sophisticated today. ${ }^{32}$ The United States has seen grow, alongside its higher standards of living, a different conception of the fitness of things. In 1900, for instance, an Tllinois statute prohibiting the use of the flag for advertising purposes, was held unconstitutional because, although such advertising might "violate the idea which soine people have of sentiment or taste," men are entitled to differ honestly on such matters and it could not be said that the statute tended "in any

"the cut of the dress, the color of the garment worn, the style of the hat, the architecture of the building or its color, may be distasteful to the refined senses of some; yet government can neither control nor regulate in such affairs." Curran Bill Posting Co. v. Denver (1910) 47 Colo. 221, 227, 107 Pac. 261, 264, 27 L. R. A. (N. s.) 548 (billboard case). The argument that the architecture of city-buildings is in the same unimpeachable category with individual taste in dress, an argument also adopted in Haller Sign Works v. Physical, etc. School, supra, is answered effectively by Ralph Straub (1924) 28 LAw Nores $68,70$.

"A nuisance is anything that worketh hurt, inconvenience, or damage to another, and the fact that the act done may otherwise be lawful does not keep it from being a nuisance. The inconvenience complained of must not be fanciful, or such as would affect only one of fastidious taste, but it must be such as would affect an ordinary, reasonable man." Italics added.

"A purpose which, although conceded to be public, is a purpose which may be described as a luxxury rather than necessity." GA. CTv. CODE, $\$ 3861 ; \S 4457$ in PARK's ANN. CODE, GA. (1914) 3, 2717; ibid. (1922) 9, 1411; ibid. (1926) 12, 715 ; ibid. (1928) 14, 579. Parker v. Commonwealth (1901) 178 Mass. 199, 204, 59 N. E. 634 (zoning case).

"The municipal authority, in endeavoring to regulate the dimensions, etc., of billboards, must refrain from making restrictious which by pandering to some aesthetic or illegal consideration amount to an interference with proprietary right beyond the extent of legal authority." Note (1909) 132 Am. St. Rep. 94. Italics added.

32 The Massachusetts court recognized this trend even thirty years ago: "Many things which a century ago were luxuries, or were altogether unknown, have now become necessaries. It is only within a few years that lands have been taken in this country for public parks. Now the right to take land for this purpose is generally recognized and frequently exercised." Attorney General v. Williams (Copley Square case) (1899) 174 Mass. 476, 479, 55 N. E. 77, 78, 47 L. R. A. 314.

In this colmection, the testimony may be adduced of a distinguished foreigner who is struck, on revisiting the United States after thirty years' absence, with the advance made, in all elements of city and country life, toward form, order and beauty. $M$. André Chevrillon, French critic and academician, writes:

"Moreover, one detail of the building is significant and of symbolic value, simce it wholly reveals the new ideal which wars against the earlier individualistic and commercial confusion: in this modern utilitarian building, this American railwaystation, not a single advertising poster is allowed." New York Après Trente Ans (1923) 14 Revue des DeuX Mondes (Series 7) 601, 616. 
way to elevate the morals or promote the welfare of the public." ${ }^{13}$ It is safe to say such a decision could not be rendered today. ${ }^{34}$

But the world, while moving, is often checked by its efficient brakes. Both Federal and state constitutions guard vested rights; any impingement upon such rights, in the public interest, becomes a social process of some duration; while this process takes place, judicial opinion must lag a considerable distance behind the public opinion that eventually shapes it.

In varying degrees this is true of every manifestation of that plenomenon of the last forty years, the increasing elasticity of the police power. This power, it will be remembered, in its first important modern pronouncement, was invoked on behalf of "public health, public morals, or the public safety,"35 and for some years there was a tendency to restrict its application to matters clearly within those three severe terms. But there is much in life that is not directly related to health, morals or safety; and as actual instances arose expressions became common to the effect that the police power could protect as well the comfort, peace, and convenience of the population. ${ }^{36}$ After thirty-odd years, the most

33 Ruhstrat v. People (1900) 185 Ill. 133, 143, 57 N. E. 41, 44; IrL. Laws 1899 , p. 235. See, in accord with Illinois case, People v. Van De Carr (1904) 178 N. Y. 425, 70 N. E. 965 . Contra: Commonwealth v. Sherman (1905) 189 Mass. 76, 75 N. E. 71; Halter v. Nebraska (1905) 74 Neb. 757, 105 N. W. 298, 121 Ain. St. Rep. 754, 7 L. R. A. (N. S.) 1079; aff'd (1907) 205 U. S. 34, 51 L. Ed. 696, 27 Sup. Ct. 419.

${ }^{34}$ An instance, nearer home, of a swift change in standards of taste is worth noting: In the California of 1881 an ordinance was held unconstitutional which prohibited a woman from being in a saloon between $6 \mathrm{p} . \mathrm{m}$. and $6 \mathrm{a} . \mathrm{m}$. Matter of Maguire (1881) 57 Cal, 604, $40 \mathrm{Am}$. Rep. 125. For the woman in question was a waitress in the saloon, and could not be disqualified "on account of sex ... from ... pursuing any lawful ... vocation." Cax. Const. 1879, Art. XX, \& 18. Within a few years this decision was tacitly overruled. Ex parte Felchlin (1892) 96 Cal. 360, 31 Pac. 224, 31 Am. St. Rep. 223; ex parte Hayes (1893) 98 Cal. 555, 33 Pac. 337, 20 L. R. A. 701. By 1894, a man who had ever indulged in the employment of a female in a saloon, "though not then prohibited by law ... has in the past shown himself willing to debauch the morals of the community to imcrease his business." Foster v. Police Commissioners (1894) 102 Cal. 483, 37 Pac. 763, 41 Am. St. Rep. 194.

35 Mugler v. Kansas (1887) 123 U. S. 623, 661-663, 31 L. Ed. 205, 8 Sup. Ct. 273.

${ }^{30}$ Ex parte Whitwell (1893) 98 Cal. 73, 78, 32 Pac. 870, 872, 35 Am. St. Rep. $152,155,19$ L. R. A. 727, 730. Such general phrases as "the coinmon advantage" (People v. Williamson (1902) $135 \mathrm{Cal} .415,419,67 \mathrm{Pac}$. 504, 505), "the common good" (ex parte Yun Quong (1911) 159 Cal. 508, 511, 114 Pac. 835, 836, Ann. Cas. 1912C 969), "the coinfort and welfare of society" (Ingram v. Colgan (1895) 106 Cal. 113, 122, 38 Pac. 315, 316, 46 Am. St. Rep. 221, 28 L. R. A. 187) begin to appear and soon abound (see, for instances, 1893-1914, Bufford, The Scope and Meaning of Police Power (1916) 4 CAIIFORNIA L. REv. 269, 279, 280, n. 42; for later cases, 18 Car. Jur. 819 et seq., Treadwert, CaL. Const. (1923) 604-620). The original trinity of "health, morals and safety" on occasion becomes one of "welfare, health and morals." Ex parte Hayden (1905) 147 Cal. 649, 650, 82 Pac. 315, 316, 109 Am. St. Rep. 183, 1 L. R. A. (N. s.) 184; ex parte Drexel (1905) 147 Cal. 763, 766, 82 Pac. 429, 431, 2 L. R. A. (N. S.) 588; or of "safety, comfort and health." County of Plumas v. Wheeler (1906) 149 Cal. 758, 762, 87 Pac. 909, 911. 
elastic term possible - "the general welfare" - is most commonly used to define the broad scope of the power. ${ }^{37}$ Eventually also the conception of what constitutes the general welfare is frankly recognized to be a flexible one, changing with the times and dependent on public opinion. Mr. Justice Holmes then says:

\begin{abstract}
"It may be said in a general way that the police power extends to all the great public needs. It may be put forth in aid of what is sanctioned by usage, or held by the prevailing morality or strong and preponderant public opinion to be greatly and immediately necessary to the public welfare."38
\end{abstract}

On rehearing he hastens to add that by this statement the Court has not intended "to give a new or wider scope to the power."39 Nevertheless, his language above quoted, to the effect that preponderant public opinion determines that scope, so meets the needs of the times that immediately, and since, other courts have availed themselves of it to support their own extending views. ${ }^{\text {to }}$

In matters of health, or of moral judgment, the police power admittedly tends to keep more nearly abreast of the times than it does in the mooted field of aesthetics, where its exercise must yet in many instances be justified by indirection. Whether this difference will continue remams to be seen. Not so long ago the charge that a law was in any degree motivated by "aesthetic" considerations was enough to damn it utterly; now, that word no longer spells folly to the ears of many of the courts; some day, it may spell wisdom, as it already does to one or two. Today, in the matter of billboards, especially of those that deface the countryside, as opposed to those in the cities, the process of change is by no means complete. The day of Silas Lapham is past; the day when a phrase such as "the preservation of the amenities of the landscape" is generally accepted has not yet dawned. For this reason there may be value in digressing, for a moment, to consider an integrally allied sub-

37 Miller v. Board of Public Works (1925) 195 Cal. 477, 485, 487-490, 234 Pac. 381, 38 A. L. R. 1479, and cases cited.

38 Noble State Bank v. Haskell (1911) 219 U. S. 104, 111, 55 L. Ed. 112, 31 Sup. Ct. 186. Cf. Miller v. Schoene (1928) 276 U. S. 272, 279-280, 48 Sup. Ct. $246,247$.

39219 U. S. 575, 580, 55 L. Ed. 341, 31 Sup. Ct. 299.

40 McDavid v. Bank of Bay Minette (1915) 193 Ala. 341, 69 So. 452; Miller v. Board of Public Works, supra n. 37; State v. Phillips (1915) 109 Miss. 22, 36, 67 So. 651, 653; Cunningliain v. Northwestern Imp. Co. (1911) 44 Mont. 180, 119 Pac. 554; Wulfsohn v. Burden (1925) 241 N. Y. 288, 299, 150 N. E. 120, 123; Churchill v. Rafferty (1915) 32 Philippine Rep. 580, 604, 610; Hopkins v. Richmond (1915) 117 Va. 692, 86 S. E. 138; Gorieb v. Fox (1926) 145 Va. 554, 134 S. E. 914; State v. Mountain Timber Co. (1913) 75 Waslt. 581, 135 Pac. 645, L. R. A. 1917D 10; State v. Harper (1923) 182 Wis. 148, 196 N. W. 451, 33 A. L. R. 269. 
ject,-that of protecting and amplifying the beauty of our cities, - where the process is already fairly complete.

\section{THE GROWTH OF ZONING IN AMERICAN CITIES}

This need not take us long. The legislative and judicial facts are readily available. ${ }^{41}$ After a certain period of trial, during which ancient and new standards measured strength, zoning has swept the country. Prior to October, 1921, only 48 cities and towns had adopted zoning ordinances; by the end of 1923 this number had grown to 218; on January 1,1926 , "there were at least 425 zoned nuunicipalities, comprising more than half the urban population of the country"; $; 2$ on July 1 , 1927 , the zoned municipalities had grown to $553 ;^{43}$ by January 1,1928 , their number had increased to 583 , and thirty-one millions lived within the zoned areas. ${ }^{44}$ The list includes New York, Chicago, St. Louis, Boston, Baltimore, Pittsburgh, Los Angeles and South San Francisco. San Francisco is not listed; it is zoned as to the use of buildings, but not as to their height or bulk. California, with 60 zoned municipalities, is third on the list of the states.

The statutes adopted by some thirty of the states, authorizing municipalities to zone themselves, and the municipal zoning ordinances where not unreasonable or discriminatory, have in general been upheld. The process, though in its later years achieved with cumulative rapidity, passed through several stages. At first, the movement was largely suspect; then followed a growing tendency.to support the legislation, and to find adequate reasons for such support other than "purely aesthetic"

41 Chamberlain and Pierson, Zoning Laws and Ordinances (1924) 10 AnrericaN Bar Assn. JouRnat 185, No. 3; Bettman, The Constitutionality of Zoning (1924) 37 Harvard L. Rev. 834; Note (1921) 34 Harvard L. Rev. 419; (1924) 37 HarVARD L. Rev. 390; Baker, The Constitutionality of Zoning Laws (1925) 20 Irxinoxs L. Rev. 213; Baker, Municipal Aesthetics and the Law (1926) 20 IrLINoIs L. Rev. 546; Baker, Aesthetic Zoning Regulations (1926) 25 Mranrgan I. Rev. 124; Bassett, Zoning (1920) 9 NATTONAL MUNICIPAL REv. 315 (citations and biblography, pp. 336-341) ; (1925) 12 VIRGINIA L. Rev. 65; Note (1920) 30 YaLE L. J. 171; Note (1923) 32 YaLe L. J. 833; Barer, Legax Aspects of Zoning (1927); 3 McQuitlan, LaW of Muntcipal Corporations (2d ed. 1928) § 986; Wintialas, Law of Crty Planning and Zontwg (1922).

California: Miller v. Board of Public Works, supra n. 37; Zahn v. Board of Public Works (1925) 195 Cal. 497, 234 Pac. 388; Fourcade v. San Francisco (1925) 196 Cal. 655, 238 Pac. 934; Blumenthal v. Cryer (1925) 71 Cal. App. 668, 236 Pac. 216. For other California cases: Note (1921) 9 CartForsta I. REv. 164; Note (1924) 12 CaLtrornta L. Rev. 428. CaI. Const., Art. XI, § 11; Cal. Stat. 1915, p. 708; Cal. Stat. 1917, pp. 1419, 1421; Cal. Stat. 1927, p. 708.

42 A Standard State Zoning Enabing Act, Department of Commerce, Washington (1926).

43 Zoning Progress in the United States, Department of Commerce, Washington, July, 1927.

44 Ibid. Supplement of Jan. 1, 1928. 
ones; ${ }^{45}$ in an intermediate stage, if grounds of public health and safety could be adduced to justify a zoning ordinance, even the admitted presence of "incidental" aesthetic considerations would not wholly vitiate the otherwise proper legislation; eventually, and somewhat timidly, it becomes recognized that the satisfaction of the aesthetic sense has a distinct bearing on the general welfare, and that it may properly receive a certain measure of recognition, "as auxiliary" to other more established social wants. ${ }^{46}$ Thus the needs of the eye, denied admittance to the main portal of the judicial edifice, are at last permitted access to the tradesmen's entrance. The next logical step is obvious. ${ }^{47}$

45 "Long before the days of comprehensive zoning, the American courts laid down the rule that esthetic considerations did not constitute an interest of the commumity sufficient to justify the interference with individual rights. As a result many laws which were passed for esthetic reasons had to be justified in terms that would bring them within the police power formula of liealth, safety, morals, or general welfare. For example, billboards could not he suppressed because they were unsightly but were suppressed as having a tendency to afford a shield for immoral practices. The zoning cases have also displayed a tendency to justify zoning under the police power verbiage. With two exceptions they deprecate argument based on esthetic considerations, although it is a matter of common knowledge that esthetic considerations are very powerful motives with the city council which enacts the zoning law." Note (1925) 13 CarIFoRNIA L. Rev. 418.

"However, it is certam that inuch of the municipal legislation and regulation of late years, particularly during the past two or three decades, has been induced largely by aesthetic or artistic considerations, and this desire to render the urban centers more attractive has found a firm lodgment in the popular mind. It is destined to increase with the years, and in the development of the law in this respect courts will incline more and more to give a broader interpretation to such regulations, and finally sanction restrictions imposed solely to advance material attractiveness and artistic beauty." 3 McQunIIn, Tre Law of Municrpal CorPORATIONS ( $2 \mathrm{~d}$ ed. 1928) § 943.

46 Welch v. Swasey (1909) 214 U. S. 91, 108, 53 L. Ed. 923, 29 Sup. Ct. 567; St. Louis Poster Advg. Co. v. St. Louis (1919) 249 U. S. 269, 274, 63 L. Ed. 599, 39 Sup. Ct. 274; State v. New Orleans (1923) 154 La. 271, 284, 97 So. 440, 444, 33 A. L. R. 260; York Harbor v. Libby (1928) 126 Me. 537, 542, 140 Atl. 382, 386; Welch v. Swasey (1907) 193 Mass. 364, 375, 79 N. E. 745, 746, 23 L. R. A. (N. s.) 1160; Opinion of the Justices (1920) 234 Mass. 597, 127 N. E. 524; Ayer v. Commissioners (1922) 242 Mass. 30, 136 N. E. 338; Wulfsohn v. Burden, supra n. 40; In re Liggett (1927) $291 \mathrm{~Pa} .109,116,139$ Atl. 619, 623. In Opinion of the Justices, supra, a zoning bill was awarded constitutional rating even though it expressly stated that its provisions were to be carried out "in such manner as will best promote the health, safety, convenience and welfare of the imhabitants, will lessen the danger from fire, will tend to improve and beautify the city or town, will harmonize with its natural development, and will assist the carrying out of any schemes for municipal improvement put forth by any municipal planning board or board of "survey or other like authority." 234 Mass. at 599. Italics added.

And the Court goes so far as to point out that the Supreme Court of the United States has never squarely decided "that the exercise of the police power cannot rest on aesthetic considerations alone as its sole basis," although it admits the inference that "at present at all events" such would be its decision. 234 Mass. at 604 . Cf. (1913) 26 Harvard L. REv. 367, 368. New York's Municipal Empowering Act expressly recognizes "the promotion of beauty" as a public purpose. N. Y. Laws 1913, c. $247, \S 21$.

47 "The operation of zoning proceeds apace, forcing the jurisprudence of the 
This process, here given in broad outline, is not everywhere at the same point today; in a number of jurisdictions two of its several stages yet overlap; in at least two or three the old viewpoint prevails to an extreme degree; ${ }^{48}$ occasionally in a single decision as many as three divergent social viewpoints find judicial expression. ${ }^{49}$ But on the whole public opinion has grown, in the matter of zoning, to maturity. The statement of the Supreme Court of Errors of Connecticut is justified:

"A few years ago it was, so far as the rule had been announced, undoubted that restrictions could not be imposed upon private property solely for aesthetic considerations. Later it has been said by high authority that aesthetic considerations may be regarded in connection with recognized police power considerations. And now Dillon in the latest edition of his Municipal Corporations, sec. 695, says:

"The law on this point is undergoing development, and perhaps cannot be said to be conclusively settled as to the extent of the pohice power." "so

\section{San Franctsco, CaLifornia.}

Chauncey Shafter Goodrich.

\section{(To be Concluded)}

acquisitive process to yield, slowly indeed but inexorably, before the movement of social forces." Beard, Conflicts in City Planning (1927) 17 YaLe RevIEw No. 1.

$C f$. Judge Charles $M$. Hough: "The direct appeal of property to due process has for the most part failed; and apparent successes have but taught legislators how to arrive at the same result in another way. The indirect appeal through liberty is still going on, for the American belief that every freeman can do what he likes, where and when he pleases, as long as he does not infringe the moral law as expressed in the usual criminal code, dies very hard. But it is dying, and the courts, when invoked today under the due-process clause, are doing little more than easing the patient's later days." Hough, Due Process of Law Today (1919) 32 Harvard L. Rrv. 218, 233.

18 Smith v. Atlanta (1926) 161 Ga. 769, 132 S. E. 66; Goldman v. Crowther (1925) 147 Md. 282, 128 Atl. 50, 38 A. L. R. 1455; Ignaciunas v. Nutley (1924) 99 N. J. L. 389, 125 Atl. 121; cf. Ignaciunas v. Nutley (1923) 98 N. J. L. 712, 121 Atl. 783.

49 One of the most instructive of these is Thille v. Board of Public Works (1927) 82 Cal. App. 187, 255 Pac. 294, where the same District Court of Appeal which had refused validity to the ordinance considered in the Zahn case (March 20, 1924, 43 Cal. App. Dec. 663) on the authority of the final disposition made of that appeal (195 Cal. 497, 234 Pac. 388) and of the Miller case (195 Cal. 477, 234 Pac. 381) sustains a "set-back" ordinance. All three justices write opinions. One of these freely accepts the new order. Another, concurring, does so under protest against the recent invasions of the police power on property rights, but admits with some grace:

"It may be that some of these later applieations of that power, in the control of property rights, present themselves to our minds in the aspect of something arbitrary while they are new, but will seem less objectionable when our independent souls become accustomed to the new bonds. As the individual withers and as his frontiersman spirit is tamed, he will more easily recognize that when he lives in Rome and owns property there he must submit to the conditions which the Romans prescribe." 82 Cal. App. at 198.

The third opinion is a strong dissent, on the old familiar ground:

"On a fairly wide street, in a residence district, the only consideration which can be reasonably urged for the passage of such an ordinance is that without it the beauty of the street will be marred; in other words, the reason is founded solely on aesthetical considerations." 82 Cal. App. at 199.

50 Windsor v. Whitney (1920) 95 Conn. 357, 368, 111 Atl. 354, 357, 12 A. L. R. 669. 